\title{
Breeding Objective, Selection Criteria and Breeding Practice of Indigenous Goat Types in Ancher and Gemechis Districts, Eastern Ethiopia
}

\author{
Mohammed Yousuf ${ }^{1, ~ *}$, Tesfaye Getachew ${ }^{2}$, Elias Bayou ${ }^{3}$ \\ ${ }^{1}$ Department of Animal Science, Mizan Tepi University, Mizan Teferi, Ethiopia \\ ${ }^{2}$ International Center for Agricultural Research in the Dry Areas (ICARDA), Addis Ababa, Ethiopia \\ ${ }^{3}$ Department Animal Science, Mizan Tepi University, Mizan Teferi, Ethiopia
}

Email address:

mahammedyousuf1@gmail.com (M. Yousuf), tesfayegecho@yahoo.com (T. Getachew), eliasbayou2009@yahoo.com (E. Bayou)

${ }^{*}$ Corresponding author

\section{To cite this article:}

Mohammed Yousuf, Tesfaye Getachew, Elias Bayou. Breeding Objective, Selection Criteria and Breeding Practice of Indigenous Goat Types in Ancher and Gemechis Districts, Eastern Ethiopia. Chemical and Biomolecular Engineering. Vol. 5, No. 4, 2020, pp. 80-89.

doi: $10.11648 /$ j.cbe.20200504.12

Received: November 18, 2020; Accepted: December 1, 2020; Published: December 11, 2020

\begin{abstract}
This study was aimed to generate basic information on breeding objective, selection criteria and breeding practice of indigenous goat type under farmer's management condition in Ancher and Gemechis districts, Eastern Ethiopia. The study was performed based on household survey. About 240 households (120 from each district) were used for household survey. Appearance, color, testicular characteristics and horn were most important traits considered by farmers to choose breeding bucks in Ancher and Gemechis district. Appearance and coat color ranked as first and second, respectively followed by better milk yield in Ancher and twinning ability in Gemechis district as third criteria for selection breeding does. The average age at first sexual maturity of male in Ancher and Gemechis district were 7.6 \pm 0.07 and $7.4 \pm 0.06$ months, respectively, in the meantime female goats were the average age at first sexual maturity in Ancher and Gemechis districts was $7.8 \pm 0.07$ and 7.6 \pm 0.06 months, respectively. The mean of age at first kidding for Ancher and Gemechis districts goat $12.9 \pm 0.15$ and $12.5 \pm 0.14$ months, respectively. Mean estimate of effective population size and mean rate of inbreeding was 2.4 and 0.21 , respectively when a household flock is herded alone and under random mating. Therefore, any breed improvement strategies that are intended to be implemented in the study area and otherwise- where should consider the traditional breeding practices and breeding objectives of the community.
\end{abstract}

Keywords: Breeding System, Selection Criteria, Goat Type

\section{Introduction}

Agriculture in Ethiopia is the backbone of the country's economy and livestock is an integral part of agriculture. Ethiopia have large livestock population; comprising 59.5 million cattle, 30.70 million sheep, 30.20 million goats, 8.44 million donkeys, 2.16 million horses, 1.21 million camels, 0.41 million mules and 56.53 million poultry [1]. It is eminent that livestock products and by-products in the form of meat, milk, honey, eggs, cheese, and butter supply provide the needed animal protein that contributes to the improvement of the nutritional status of the people. Livestock also plays an important role in providing export commodities, such as live animals, hides and skins to earn foreign exchanges to the country [1] Goats are browsers and are selective feeders and thus it enables them to thrive on sparse bushes and shrubs they also have broad feeding habits and short reproductive cycle, which provide goats with comparative advantage over other species [2]. It important for diversifying agriculture and livestock production, creating employment opportunities, improving family income, building capital, contributing to human nutrition and reducing risk like those of vagaries of nature, in addition to their quantifiable outputs of several products [3]. Goats are reared under diverse agro-ecological zones from arid to cold and over in a wide range of production systems. Goats kept 
in different parts of the country for the purpose of food source, income generation, socio-cultural wealth and source of other valuable non-food products used as raw materials for various traditional household products manufactured in local cottage industries. The genetic improvement of livestock involves identification of the breeds or strains of livestock reared in the country and also the type of environment in which they are reared, this involves the description of the breed, moreover, successful livestock improvement programs involves the compatibility of the genotypes with those of the breeding objectives of the rearers and the production systems [4]. Pastoralists/smallholder farmers have very valuable knowledge about animal management and desirable traits but less knowledge on how genes are transmitted to the next generation and how to use information from relatives [5]. Currently, community based genetic improvement strategies are being advocated for pastoral production [6]. These strategies would require a good understanding of the community's indigenous knowledge of their animals. Even though the importance of knowing the communities breeding practices, selection criteria and herding practices such information is scanty for indigenous goats in the study area. Therefore, this research was under taken to describe farmer's selective breeding objectives, selection criteria and breeding system in Ancher and Gemechis districts, East Ethiopia.

\section{Materials and Methods}

\subsection{Description of the Study Area}

The study was conducted in Ancher and Gemechis districts, Eastern Ethiopia. Ancher is located $9^{\circ} 0$ 'North Latitude and $40^{\circ} 0^{\prime}$ East Latitude and $8^{0} 30^{\prime}$ 'North Latitude and $40^{\circ} 25^{\prime}$ 'East Latitude. It is capital town, Cheleleka, is located at a distance of $75 \mathrm{~km}$ from the city of Metahara town and is found at a distance of 265 kilometers from Addis Ababa. District extends between 960-3220 meters above sea level. With regard to land feature, $85 \%$ is mainly rolling while forest exists in 8 of the kebeles. Ancher district is classified into highland, midland, and lowland agro-climatic zones, covering about 13\%, 24\% and $63 \% \%$ of the total area of the district, respectively. The district receives an average mean annual rain fall and temperature ranging between $900-1200 \mathrm{~mm}$ and $07^{\circ} \mathrm{C}-38^{\circ} \mathrm{C}$, respectively, manly the district rain fall pattern is bi-modal. Gemechis is located at $343 \mathrm{~km}$ east of Addis Ababa and about $17 \mathrm{~km}$ south of Chiro, capital town of the zone. It shares borders with Chiro district in the west and north, Oda Bultum district in the south and Mesala district in the east. The district is found within 1300 to 2400 meters above sea level (m.a.s.1). It receives an average annual rainfall of $850 \mathrm{~mm}$.

\subsection{Site Selection and Sampling Techniques}

The sampling method employed for this study was multistage purposive sampling technique, which was based on the potential of goat production. Accordingly sampling sites or rural 'kebeles' each representing different agro- ecology were selected in each district, based on goat flock size per household, accessibility and suitability of the area for goat production. From each rural kebeles, 40 household heads having indigenous goat breed were randomly selected for interview. Generally, 240 households (120 household from each district) were selected from the six rural kebeles (sampling sites) from the two study districts.

\subsection{Data Type and Method of Data Collection}

A modified questionnaire was prepared by adopting a questionnaire prepared by adopting a questionnaire prepared by ILRI (International Livestock Research Institute)-OADB (Oromiya Agricultural Development Bureau) for survey of livestock breeds in Oromiya [7]. The questionnaire was pretested before administration and some re-arrangement, reframing and correcting in accordance with respondent perception were done. The questionnaire was administered to the randomly selected household heads or representatives by a team of enumerators recruited and trained for the purpose with close supervision by the researcher.

For focused group discussions, 10 household heads were selected in each rural kebeles and group discussion was conducted with extension employees and Developmental Agents (DAs) since it is believed that such individuals have better information about the overall production potential of the breed as well as the information regarding the origin of breed, trend in population, special characters of the breed, selection criteria, production system, husbandry and fattening practice, breeding methods, production constraints and major constraints to maintain the breed and purpose of keeping goat were collected from group discussions.

\subsection{Data Management and Analysis}

The data collected from each study site was checked for any error and corrected during the study period, coded and entered into computer for further analysis.

Questionnaire data: Data collected through questionnaire was described by descriptive statistics using Statistical Package for Social Sciences (SPSS version 20) [8]. Chisquare was employed when required to test the independence of categorical variables and to assess association between levels of categorical variables. Ranked data were evaluated based on calculated indices. An index was calculated to provide overall ranking for qualitative data such as, purpose of keeping goat, selection criteria of females and males according to the following formula: Index $=\Sigma$ of [ 3 for rank $1+2$ for rank $2+1$ for rank 3] given for particular qualitative variables divided by $\Sigma$ of [ 3 for rank $1+2$ for rank $2+1$ for rank 3] for all qualitative variables considered.

The rate of inbreeding from effective population size for a randomly mated population was calculated as $\mathrm{Ne}=(4 \mathrm{Nm} \mathrm{Nf})$ $/(\mathrm{Nm}+\mathrm{Nf})$ Where, $\mathrm{Ne}=$ effective population size, $\mathrm{Nm}=$ number of breeding males and $\mathrm{Nf}=$ number of breeding females. The rate of inbreeding coefficient $(\Delta \mathrm{F})$ was calculated from $\mathrm{Ne}$ as $\Delta \mathrm{F}=1 / 2 \mathrm{Ne}[9]$. 


\section{Results and Discussions}

\subsection{Castration}

The percentage of households who practiced buck castration and method of castration used are presented in Table 1. The proportion of households who practiced castration and the average age of castration varied from place to place. Majority (92.5\%) of households in the study area practiced castration while about $7.4 \%$ of household do not practiced castration. There was no significant association between districts $(P>0.05)$ and castration practiced. However the current finding was in agreement with the report of [10] in Shabelle zone who reported that about $93.7 \%$ of respondents practiced castration and the finding correspond with the work of [11] who reported that castration was practiced $(70.99 \%)$ of the sampled household in Eastern Hararghe. Body confirmation, age, color and physical characteristics were major characteristics used to select for male goat for castration in the study area presented in (Table 1). There was no significant association between district $(P>0.05)$ and selection criteria for castration male. Above half (61.4\%) of households in Ancher district reported body confirmation was major selection criteria for male castration followed by age $(29.5 \%)$ and $(8.8 \%)$ color while in Gemechis district $(67.6 \%)$ of households reported body confirmation was selection criteria for castration male goat followed by age $(25.9 \%)$ and color $(6.5 \%)$. Selecting animals with good body confirmation by most farmers may be they usually have notice-able muscle development and fat deposition that make them attractive in the market after they are fed.

In both districts, age is important selection criteria next to body confirmation during castration because very young male goat cannot recover easily and go to the fattening stage (fat deposition). Therefore, farmers select stronger male goat with good body confirmation as selection criteria for castration. According to group discussion with participants, physical characteristics like body length and height were given priority when selecting male goats for castration. This may be due to its relation with local market demand as it is area of fat deposition, which is the interest of local consumers. In most cases, brown are the dominant colors in the study area; so brown color is preferred color in both district for castration male goat. Age has been one of the criteria in selecting male goat for castration. The main age of castration was from one year to two year $(88.3 \%)$ followed by greater than 2 year $11.7 \%$. there was no significant association between districts $(P>0.05)$ and age of castration.

In the study area most $(84.7 \%)$ of households practiced modern castration method by using Burdizo castrator; this was made by animal science experts at animal health station or veterinary clinic. On the other hand, rarely $(15.3 \%)$ of the respondents, apply traditional castration methods by using locally available materials like wood and stones locally known as (Gonjollo and Dhagaa), respectively and this was no significant association between districts $(P>0.05)$ and castration method. The motivation for the castration of goats across the two surveyed areas was mainly to improve fattening to get better price in local markets. Most of the respondents in the study area were supply feed $(100 \%)$ for their castrated goats. The main feed they supplied was concentrate; chat leaves (Geraba), home left over, local brewery byproduct, grass, $41.9 \%, 27.9 \%, 18 \%, 4.1 \%$, and $8.1 \%$ respectively.

Table 1. Castration of goats in study area.

\begin{tabular}{|c|c|c|c|c|c|}
\hline & \multicolumn{2}{|c|}{ District (N \%) } & \multirow[t]{2}{*}{ Overall } & \multirow{2}{*}{$\mathbf{X}^{2}$} & \multirow{2}{*}{ p-value } \\
\hline & Ancher & Gemechis & & & \\
\hline Castration buck & & & & 2.16 & 0.14 \\
\hline Yes & $114(95)$ & $108(90)$ & $222(92.5)$ & & \\
\hline No & $6(5)$ & $12(10)$ & $18(7.5)$ & & \\
\hline Primary selection criteria for castration & & & & 4.5 & 0.35 \\
\hline Body confirmation & $70(61.4)$ & $73(67.6)$ & $143(64.4)$ & & \\
\hline Age & $34(29.5)$ & $28(25.9)$ & $62(27.9)$ & & \\
\hline Color & $10(8.8)$ & $7(6.5)$ & $17(7.7)$ & & \\
\hline Reason for castration & & & & 2.63 & 0.11 \\
\hline Improve fattening & $80(70.2)$ & $86(79.6)$ & $166(74.8)$ & & \\
\hline Better price & $34(29.8)$ & $22(20.4)$ & $56(25.2)$ & & \\
\hline At what age do you castrate & & & & 1.22 & 0.27 \\
\hline $1-2$ year & $98(86)$ & $98(90.7)$ & $196(88.3)$ & & \\
\hline$>2$ year & $16(14)$ & $10(9.3)$ & $26(11.7)$ & & \\
\hline \multicolumn{6}{|l|}{ Supplementary feed for castration goat } \\
\hline Yes & $114(100)$ & $108(100)$ & $222(100)$ & & \\
\hline No & - & - & -- & & \\
\hline \multicolumn{6}{|c|}{ Type of supplementary feed for castrated goat } \\
\hline Concentrate & $46(40.4)$ & $47(43.5)$ & $93(41.9)$ & & \\
\hline Chat & $31(27.2)$ & $31(28.7)$ & $62(27.9)$ & & \\
\hline Home left over & $23(20.2)$ & $17(15.7)$ & $40(18.0)$ & & \\
\hline Local brewery byproduct & $5(4.4)$ & $4(3.7)$ & $9(4.1)$ & & \\
\hline Grass & $9(7.9)$ & $9(8.3)$ & $18(8.1)$ & & \\
\hline Methods of castration & & & & 5.95 & 0.02 \\
\hline Modern & $90(78.9)$ & $98(90.7)$ & $188(84.7)$ & & \\
\hline Traditional & $24(21.1)$ & $10(9.7)$ & $34(15.3)$ & & \\
\hline
\end{tabular}

$\mathrm{N}=$ number of household $\mathrm{X}^{2}=$ Pearson chi-square 


\subsection{Fattening and Constraints}

A total of $94.6 \%$ households in the study area $(92.5 \%$ of the household in Ancher and $96.7 \%$ of respondents in Gemechis) were practiced goat fattening presented in (Table $2)$. This result in contrast with the report of [4] in Bale zone were $(79.2 \%)$ of respondents not practiced fattening.

Farmers in the study areas practice fattening both during wet season $(75.8 \%)$ and dry season $(24.2 \%)$. This might be farmers get high income from fattening by using supplementary feed in both seasons and high demand of meat at both seasons. Fattening duration in Ancher district was $(47.7 \%, 47.7 \%)$ while in Gemechis district $(63.8 \%, 34.5 \%)$ at 3-4 and 4-6 months, respectively. Might be there is variation in feed availability in the area and management system within individual farmers. The mean age of fattening in Ancher and Gemechis districts was 13.9 and 12.5 months, respectively. This may be traditional fattening or lack of knowledge about age for fattening consider as selection criteria especially in Ancher district.

Table 2. Fattening practices in the study area.

\begin{tabular}{|c|c|c|c|c|c|}
\hline & \multicolumn{2}{|c|}{ Districts (N \%) } & \multirow{2}{*}{ Overall } & \multirow{2}{*}{$\mathbf{X}^{2}$} & \multirow{2}{*}{ p-value } \\
\hline & Ancher & Gemechis & & & \\
\hline Fattening practice & & & & 2.03 & 0.15 \\
\hline Yes & $111(92.5)$ & $116(96.7)$ & $227(94.6)$ & & \\
\hline No & $9(7.5)$ & $4(3.3)$ & $13(5.4)$ & & \\
\hline Mean age of fattening & $13.9 \pm 0.46$ & $12.5 \pm 0.45$ & $13.2 \pm 0.36$ & & 0.03 \\
\hline Season of fattening & & & & 0.43 & 0.5 \\
\hline Wet season & $82(73.9)$ & $90(77.6)$ & $172(75.8)$ & & \\
\hline Dry season & $29(26.1)$ & $26(22.4)$ & $55(24.2)$ & & \\
\hline Duration of fattening & & & & 6.5 & 0.04 \\
\hline 3-4 month & $53(47.7)$ & $74(63.8)$ & $127(55.9)$ & & \\
\hline 4-6 month & $53(47.7)$ & $40(34.5)$ & $93(41)$ & & \\
\hline$>6$ month & $5(4.5)$ & $2(1.7)$ & $7(3.1)$ & & \\
\hline Type of feed resource you use to fatten goat & & & & 1.10 & 0.78 \\
\hline Natural pasture & $3(2.7)$ & $3(2.6)$ & $6(2.6)$ & & \\
\hline $\mathrm{CONC}+\mathrm{Chat}$ & $75(67.6)$ & $80(69)$ & $155(68.3)$ & & \\
\hline $\mathrm{NP}+\mathrm{Chat}$ & $10(9.0)$ & $14(12.1)$ & $24(10.6)$ & & \\
\hline $\mathrm{NP}+\mathrm{CONC}$ & $23(20.7)$ & $19(16.4)$ & $42(18.5)$ & & \\
\hline
\end{tabular}

$\mathrm{N}=$ number of house hold $\mathrm{NR}=$ crop residues $\mathrm{CONC}=$ concentrate $\mathrm{NP}=$ ntural pasture $\mathrm{X}^{2}=$ Pearson chi-square

The major constraint for fattening in the study area were feed /shortage of land, lack of money, disease, lack of credit, market problem and labor shortage represented in Table 3. Feed shortage was most limiting constraint among the other constraint in the study area (29\%) for fattening. In Ancher district major constraint of fattening next to the feed shortage $(27 \%)$ was market problem $(25.2 \%)$ followed by lack of money (14.4\%). However, in Gemechis district the major constraint of fattening was feed shortage (31\%) followed by disease (28.4\%) and lack of money (15.5\%), respectively.

Table 3. Constraints of fattening in the study area.

\begin{tabular}{llll}
\hline & \multicolumn{2}{l}{ District (N \%) } & \multirow{2}{*}{ Overall } \\
\cline { 2 - 3 } & Ancher & Gemechis & \\
\hline Constraints & & & $66(29)$ \\
Feed/land shortage & $30(27)$ & $36(31)$ & $34(15)$ \\
Lack of money & $16(14.4)$ & $18(15.5)$ & $48(21.1)$ \\
Disease & $15(13.5)$ & $33(28.4)$ & $18(7.9)$ \\
Lack of credit & $12(10.8)$ & $6(5.2)$ & $38(16.7)$ \\
Market problem & $28(25.2)$ & $10(8.6)$ & $23(10.1)$ \\
Labor shortage & $10(9)$ & $13(11.2)$ & \\
\hline
\end{tabular}

$\mathrm{N}=$ number of household

\subsection{Purposes of Keeping Goats}

In the study area, goats kept as source of cash income, meat, manure, milk, saving and skin presented in (Table 4).
According to the respondents, goat manure is believed to have extremely important for soil fertility specially farmers used for chat farming areas locally known as (Jiddoo) which is used for the cash income, this income saved and used at the time of the wedding family, purchase of draft oxen used for plough, pay tax for government, and for s purchase of the house building materials such as iron sheet and too (group discussion). Next to the chat income get from the goats, which is used for the purchased of salt, oil, textbook for the children, school cloth and so on. In addition to this purpose of keeping goat in the study area, Muslim peoples used goatskin traditionally at the time of the knee down as carpet locally known as (Sijaja) (foal group discussion). Ranks for purposes of keeping goat in Ancher and Gemechis districts was the same even though, the index value for each of the purpose are different. The farmers in Ancher district were rearing their goats primary for cash income followed by meat, manure, milk, saving, skin with an index of $0.37,0.22$, $0.17,0.15,0.03$ and 0.05 , respectively in (Table 4). Similarly many respondents in Gemechis district were rearing their goats primary for cash income followed by meat, manure, milk, saving, skin with an index of $0.42,0.22,0.16,0.11$, 0.04 and 0.06 , respectively Table 4 . The overall purpose of goat rearing in the study area is cash income by farmers as first ranked. Different studies in Ethiopia concerning goat production objectives indicated that cash income is the 
primary purpose of goat production by the respective goat keepers. For occurrence [12] on Abergalle and Central Highland goat, [13] on indigenous Nuer goats in Nuer zone of Gembella Regional state and [14] on Bati and Borena goat breeds, reported that cash income was the first rank among different goat production objectives. The present study analogous with the report of [15] in Bale zone and report of [10] in Shabelle zone, reported that milk production was the first rank among different purpose of keeping goats in the study area.
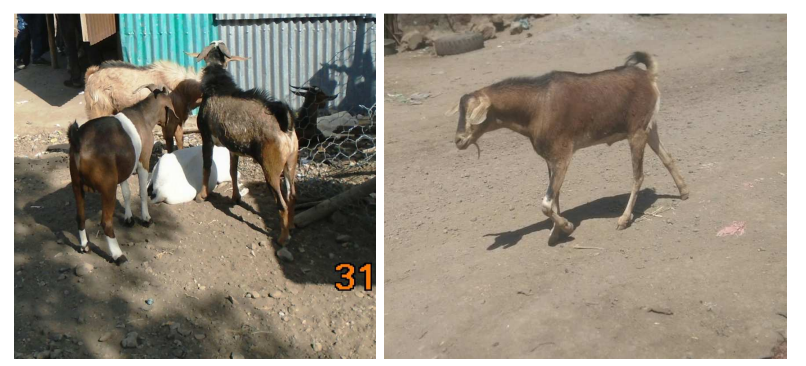

Figure 1. Castrated male in Ancher district (left) Castrated male in Gemechis district (right).

Table 4. Purpose of goat keeping in each district and ranking of these purposes.

\begin{tabular}{|c|c|c|c|c|c|c|c|c|}
\hline & \multicolumn{8}{|c|}{ Districts } \\
\hline & \multicolumn{4}{|l|}{ Ancher } & \multicolumn{4}{|c|}{ Gemechis } \\
\hline & R1 & R2 & R3 & I & R1 & $\mathbf{R 2}$ & R3 & I \\
\hline \multicolumn{9}{|l|}{ Purpose } \\
\hline Income & 86 & 5 & 0 & 0.37 & 90 & 11 & 7 & 0.42 \\
\hline Meat & 16 & 46 & 20 & 0.22 & 9 & 37 & 56 & 0.22 \\
\hline Manure & 11 & 22 & 44 & 0.17 & 9 & 36 & 19 & 0.16 \\
\hline Milk & 3 & 36 & 30 & 0.15 & 5 & 24 & 15 & 0.11 \\
\hline Saving & - & 5 & 18 & 0.04 & 1 & 4 & 16 & 0.03 \\
\hline Skin & 4 & 6 & 8 & 0.05 & 6 & 8 & 7 & 0.06 \\
\hline
\end{tabular}

$\mathrm{R} 1, \mathrm{R} 2$ and $\mathrm{R} 3=\operatorname{rank} 1,2$ and 3, respectively. Index $=\operatorname{sum}$ of $(3 \mathrm{X}$ number of household ranked first $+2 \mathrm{X}$ number of household ranked second $+1 \mathrm{X}$ number of household ranked third) give for each purpose of goat keeping divided by sum of ( $3 \mathrm{X}$ number of household ranked first $+2 \mathrm{X}$ number of household ranked second $+1 \mathrm{X}$ number of household ranked third) for all purpose of keeping goat.

\subsection{Selection Criteria for Breeding Bucks}

Selection criteria for breeding bucks are given in Table 5 . Appearance/body size/conformation/position and color were ranked first and second buck selection criteria in Ancher and Gemechis with an index of $0.38,0.26$ and $0.31,0.25$, respectively. Testicular characteristic was selected as third buck selection criteria in Ancher district with an index 0.15 whereas, horn of buck is consider as third buck selection criteria in Gemechis district with an index 0.19. According to the group discussions held, the community associate buck testicle orientation with milk yield of his offspring. They told me that buck with splited testicle towards the end is sign of good milk potential. Polled bucks were also preferred for meat, milk purpose, fattening and twining ability. Different studies in Ethiopia concerning selection criteria for breeding buck indicated that appearance and coat color is rank as first and second selection criteria for breeding buck by the respective goat keepers. For observable fact, the reports of [15] in Bale zone, [14] on indigenous Bati goats in Bati area, reported that appearance and coat color was the first and second ranks with different selection criteria for breeding buck, respectively.

Table 5. Selection criteria for breeding buck in the study area.

\begin{tabular}{|c|c|c|c|c|c|c|c|c|}
\hline & \multicolumn{8}{|c|}{ Districts } \\
\hline & \multicolumn{4}{|c|}{ Ancher } & \multicolumn{4}{|c|}{ Gemechis } \\
\hline & R1 & $\mathbf{R 2}$ & R3 & I & R1 & $\mathbf{R 2}$ & R3 & I \\
\hline \multicolumn{9}{|l|}{ Selection criteria } \\
\hline Appearance & 32 & 68 & 22 & 0.38 & 44 & 21 & - & 0.31 \\
\hline Color & 51 & 9 & - & 0.26 & 20 & 30 & 20 & 0.25 \\
\hline Character & 3 & - & - & 0.01 & 5 & - & - & 0.03 \\
\hline Growth & 14 & 10 & 7 & 0.10 & 7 & 9 & 4 & 0.08 \\
\hline Testicular & 11 & 5 & 55 & 0.15 & 4 & 4 & 21 & 0.07 \\
\hline Better sexual ability & - & 5 & 17 & 0.04 & - & 4 & 12 & 0.03 \\
\hline Family history & - & 14 & 10 & 0.06 & - & 12 & 6 & 0.04 \\
\hline Horn & - & - & - & - & 15 & 15 & 32 & 0.19 \\
\hline
\end{tabular}

$\mathrm{R} 1, \mathrm{R} 2$ and $\mathrm{R} 3=\operatorname{rank} 1,2$ and 3 , respectively. Index $=$ sum of $(3 \mathrm{X}$ number of household ranked first $+2 \mathrm{X}$ number of household ranked second $+1 \mathrm{X}$ number of household ranked third) give for each selection criteria for breeding buck divided by sum of ( $3 \mathrm{X}$ number of household ranked first $+2 \mathrm{X}$ number of household ranked second $+1 \mathrm{X}$ number of household ranked third) for all selection criteria for breeding buck.

\subsection{Selection Criteria for Breeding Does}

Among selection criteria considered, appearance, color and better milk yield as first three doe selection criteria in Ancher district with an index $0.33,0.29$ and 0.15 , respectively (Table
6). Similarly, appearance, color ranked first and second in Gemechis district with an index of $0.29,0.23$, respectively, while twinning ranked as third criteria with an index 0.17 . The present report in agreement with report of [13] in Nuer 
zone (Jikawe and Lare districts) of Gambella Regional State Ethiopia, reported that appearance and coat color ranks as first and second criteria for breeding doe, respectively. Also, similar with the report of [15] in Bale zone reported that appearance and coat color ranks as the first and second criteria for breeding doe, respectively. Generally trait preferences for male and female goat in these study area like appearance/body size, disease resistance, milk yield, reproduction rate, feed shortage resistance, coat color, longevity, and growth rate, hornless. Farmers in the study area was not interest for selection of black goat because they have no consumers preference at market level, low price and farmers primary focused on the cash income.

Table 6. Selection criterion for breeding does in the study area.

\begin{tabular}{|c|c|c|c|c|c|c|c|c|}
\hline & \multicolumn{8}{|c|}{ District } \\
\hline & \multicolumn{4}{|c|}{ Ancher } & \multicolumn{4}{|c|}{ Gemechis } \\
\hline & R1 & $\mathbf{R 2}$ & $\mathbf{R 3}$ & $\mathbf{I}$ & R1 & $\mathbf{R 2}$ & R3 & I \\
\hline \multicolumn{9}{|l|}{ Selection criteria } \\
\hline Appearance & 55 & 18 & 4 & 0.33 & 41 & 27 & 4 & 0.29 \\
\hline Color & 23 & 50 & 12 & 0.29 & 23 & 33 & 10 & 0.23 \\
\hline Mothering ability & 10 & - & 11 & 0.07 & 14 & 5 & 16 & 0.11 \\
\hline Kid survival & 11 & 10 & 25 & 0.11 & 10 & 13 & 20 & 0.12 \\
\hline Short kidding interval & - & 1 & - & - & - & 1 & 5 & 0.01 \\
\hline Twinning ability & - & 3 & - & 0.01 & 0 & 2 & - & 0.17 \\
\hline Better milk yield & 4 & 21 & 29 & 0.15 & 15 & 19 & 20 & 0.01 \\
\hline Family history & - & - & 6 & 0.01 & - & - & 10 & 0.02 \\
\hline
\end{tabular}

$\mathrm{R} 1, \mathrm{R} 2$ and R3 = rank 1, 2 and 3, respectively. Index $=$ sum of $(3 \mathrm{X}$ number of household ranked first $+2 \mathrm{X}$ number of household ranked second $+1 \mathrm{X}$ number of household ranked third) give for each selection criteria for breeding doe divided by sum of ( 3 X number of household ranked first $+2 \mathrm{X}$ number of household ranked second $+1 \mathrm{X}$ number of household ranked third) for all selection criteria for breeding doe.

\subsection{Breeding Method in the Study Area}

In the study area, twenty one point two percent of the respondents have their own buck (Table 7). There was no significance association between districts $(P>0.05)$ and own breeding buck. Among the interviewed goat keepers in the study districts, (25\%) in Ancher and (17.5\%) in Gemechis had their own indigenous breeding male goat. [12] Reported the proportion of respondents who had their own indigenous breeding buck in Zinquala $97.1 \%, 98.87 \%$ in Tanqua Abergelle and $66.7 \%$ Lay Armachiho districts which were greater than Ancher and Gemechis districts when compared with the current study results. Among household having their own buck, the main source of their breeding buck was born in the flock $(70.6 \%)$ followed by purchased from the market $(29.4 \%)$. There was significance association between districts $(P<0.05)$ and source of breeding buck. Source of breeding buck in flock higher were in Ancher district when compared with Gemechis district. May be there is no information about inbreeding in Ancher district within flock. This current study in agreement with the report of [15] in Bale zone, reported that $89 \%$ of farmer's main source of breeding buck was born in the flock. Most (88.2\%) of the households did not make special management for buck $(P>0.05)$.

The main use of breeding buck in the study area was for mating purpose (98\%) followed by social culture $2 \%$ $(P>0.05)$. Household who have no their own buck have used neighbor buck (68.3\%), communal grazing area $(22.7 \%)$ and unknown $(9 \%)$ to mate their does $(P<0.05)$. Almost all $(85.8 \%$ and $85.8 \%)$ of the respondents practice selection of males and females goats, respectively. The proportion of respondents who practiced selection for breeding female in Ancher and Gemechis districts were $85.8 \%$ and $85.8 \%$, respectively. [12] Reported that the proportion of goat keeper who practiced selection for breeding female in $(96.66 \%)$ Ziquala, (93.45\%) Tanqua Abergelle which were greater than in Ancher and Gemechis districts and smaller than (83.97\%) in Lay Armachiho district when compared with the current results. Many of the households have no breeding buck across both study sites $(88.8 \%)$. Because male in the study area, castrated for fattening, slaughtered for home consumption and sale at early age for income generation.

Table 7. Buck management and its selection practices in the study are.

\begin{tabular}{|c|c|c|c|c|c|}
\hline & \multicolumn{2}{|c|}{ District (N \%) } & \multirow{2}{*}{ Overall } & \multirow{2}{*}{$\mathbf{X}^{2}$} & \multirow{2}{*}{ p-value } \\
\hline & Ancher & Gemechis & & & \\
\hline Do you have breeding bucks by your own & & & & 2.02 & 0.16 \\
\hline Yes & $30(25)$ & $21(17.5)$ & $51(21.2)$ & & \\
\hline No & $90(75)$ & $99(82.5)$ & $189(88.8)$ & & \\
\hline Source of your breeding bucks & & & & 13.22 & 0.000 \\
\hline Born in the flock & $27(90)$ & $9(42.9)$ & $36(70.6)$ & & \\
\hline Purchased from market & $3(10)$ & $12(57.1)$ & $15(29.4)$ & & \\
\hline Yes & $4(13.3)$ & $2(9.5)$ & $6(11.8)$ & & \\
\hline No & $26(86.7)$ & $19(90.5)$ & $45(88.2)$ & & \\
\hline Purpose of keeping breeding bucks & & & & 0.71 & 0.40 \\
\hline
\end{tabular}




\begin{tabular}{|c|c|c|c|c|c|}
\hline & \multicolumn{2}{|c|}{ District (N \%) } & \multirow{2}{*}{ Overall } & \multirow{2}{*}{$\mathbf{X}^{2}$} & \multirow{2}{*}{ p-value } \\
\hline & Ancher & Gemechis & & & \\
\hline Mating & $29(96.7)$ & $21(100)$ & $50(98)$ & & \\
\hline Social culture & $1(3.3)$ & - & $1(2)$ & & \\
\hline If don't have your own breeding buck, how do you make your doe & & & & 8.12 & 0.02 \\
\hline Neighboring buck & $59(65.6)$ & $70(70.7)$ & $129(68.3)$ & & \\
\hline Communal grazing area & $27(30)$ & $16(16.2)$ & $43(22.8)$ & & \\
\hline Unknown & $4(4.4)$ & $13(13.1)$ & $17(9)$ & & \\
\hline Selection practice for breeding male & & & & 8.77 & 0.003 \\
\hline Yes & $111(92.5)$ & $95(79.2)$ & $206(85.8)$ & & \\
\hline No & $9(7.5)$ & $25(20.8)$ & $34(14.2)$ & & \\
\hline Selection practice for breeding female & & & & 0.000 & 1.0 \\
\hline Yes & $103(85.8)$ & $103(85.8)$ & $206(85.8)$ & & \\
\hline No & $17(14.21)$ & $17(14.2)$ & $34(14.2)$ & & \\
\hline
\end{tabular}

$\mathrm{N}=$ number of household $\mathrm{X}^{2}=$ Pearson chi-square

Majority of the respondents in the study area were practicing uncontrolled mating (99.2\%) presented in Table 8 . There was no significant association between districts $(P>0.05)$ and mating practice. This finding was analogous with the report of [14] in Bati, Borena and siti area who reported that $88.78 \%, 98.48 \%$ and $98.26 \%$ of respondents uses uncontrolled breeding, respectively. The present result disagreement with the report of [10] in Shabelle zone (Gode, Denan and Adadle districts) reported that about $66.7 \%$, $66.7 \%, 62 \%$ of house hold practiced controlled mating, respectively. The main reason of uncontrolled mating was lack of awareness about the effect of inbreeding (72.3\%) followed by communal grazing (13.4\%).

Table 8. Types of mating practiced in the study area.

\begin{tabular}{|c|c|c|c|c|c|}
\hline & \multicolumn{2}{|c|}{ District (N \%) } & \multirow{2}{*}{ Overall } & \multirow{2}{*}{$\mathbf{X}^{2}$} & \multirow{2}{*}{ P-value } \\
\hline & Ancher & Gemechis & & & \\
\hline Type of breeding/mating practice & & & & 2.02 & 0.16 \\
\hline Controlled & $2(1.7)$ & - & $2(0.8)$ & & \\
\hline Uncontrolled & $118(98.3)$ & $120(100)$ & $238(99.2)$ & & \\
\hline Reason of uncontrolled mating & & & & 7.28 & 0.06 \\
\hline Goat graze together & $13(11)$ & $19(15.8)$ & $32(13.4)$ & & \\
\hline Lack of awareness about effect of inbreeding & $90(76.3)$ & $82(68.3)$ & $172(72.3)$ & & \\
\hline Lack/insufficient number of buck & $8(6.8)$ & $3(2.5)$ & $11(4.6)$ & & \\
\hline Shortage of grazing land & $7(5.9)$ & $16(13.3)$ & $23(9.7)$ & & \\
\hline Do you allow a buck to mate his mother & & & & 2.02 & 0.16 \\
\hline Yes & $118(98.3)$ & $120(100)$ & $238(99.2)$ & & \\
\hline No & $2(1.7)$ & - & $2(0.8)$ & & \\
\hline Do you allow a buck to mate his daughter & & & & 2.02 & 0.16 \\
\hline Yes & $118(98.3)$ & $120(100)$ & $238(99.2)$ & & \\
\hline No & $2(1.7)$ & - & $2(0.8)$ & & \\
\hline \multicolumn{6}{|l|}{ Do you allow a buck to mate his sister } \\
\hline Yes & $118(98.3)$ & $120(100)$ & $238(99.2)$ & 2.02 & 0.16 \\
\hline No & $2(1.7)$ & - & $2(0.8)$ & & \\
\hline
\end{tabular}

$\mathrm{SE}=$ standard error $\mathrm{N}=$ number of household $\mathrm{X}^{2}=$ Pearson chi- square

\subsection{Effective Population Size and Rate of Inbreeding}

The effective population size $(\mathrm{Ne})$ and the rate of inbreeding $(\Delta \mathrm{F})$ calculated for goat flock in the study area is presented in Table 9. When goat flocks of a household were not mixed, $\Delta \mathrm{F}$ for goat in, Ancher and Gemechis districts were 0.21 and 0.19 , respectively. Based on the result obtained in this study the goat flocks (on average 3.3 and 3.1 in Ancher and Gemechis districts, respectively) were mixed together. The value was higher than the maximum acceptable level of 0.063 [16]. When flocks were mixed, the rate of inbreeding $(\Delta \mathrm{F})$ was reduced by $71.42 \%$ in Ancher and $68.42 \%$ in Gemechis goat flocks, respectively.

Table 9. Effective population size and rate of inbreeding of goats flock in the study area.

\begin{tabular}{|c|c|c|c|c|c|c|c|c|c|c|c|}
\hline \multicolumn{4}{|c|}{ Ancher } & \multicolumn{4}{|c|}{ Gemechis } & \multicolumn{4}{|l|}{ Over all } \\
\hline \multicolumn{4}{|c|}{ When flock are not mixed } & \multicolumn{4}{|c|}{ Districts } & \multirow[b]{2}{*}{$\mathrm{Nm}$ (mean) } & \multirow[b]{2}{*}{$\mathrm{Nf}$ (mean) } & \multirow[b]{2}{*}{$\mathrm{Ne}$} & \multirow[b]{2}{*}{$\Delta \mathrm{F}$} \\
\hline $\mathrm{Nm}$ & $\mathrm{Nf}$ & $\mathrm{Ne}$ & $\Delta \mathrm{F}$ & $\mathrm{Nm}$ & $\mathrm{Nf}$ & $\mathrm{Ne}$ & $\Delta \mathrm{F}$ & & & & \\
\hline 0.7 & 4.1 & 2.39 & 0.21 & 0.8 & 4.0 & 2.67 & 0.19 & 0.75 & 4.05 & 2.53 & 0.20 \\
\hline \multicolumn{12}{|c|}{ When flock are mixed } \\
\hline $\mathrm{Nm}$ & $\mathrm{Nf}$ & $\mathrm{Ne}$ & $\Delta \mathrm{F}$ & $\mathrm{Nm}$ & $\mathrm{Nf}$ & $\mathrm{Ne}$ & $\Delta \mathrm{F}$ & $\mathrm{Nm}$ & $\mathrm{Nf}$ & $\mathrm{Ne}$ & $\Delta \mathrm{F}$ \\
\hline 2.31 & 13.53 & 7.89 & 0.06 & 2.48 & 12.4 & 8.27 & 0.06 & 2.4 & 12.97 & 8.1 & 0.06 \\
\hline
\end{tabular}

$\mathrm{Nm}=$ number of male; $\mathrm{Nf}=$ number of female; $\mathrm{Ne}=$ effective population size; $\Delta \mathrm{F}=$ rate of inbreeding. 


\subsection{Reproductive Performance of Goats}

Reproductive performances of goats in the study area are presented in Table 10. The average age at first sexual maturity of male in Ancher and Gemechis district were $7.6 \pm 0.07$ and $7.4 \pm 0.06$ months, respectively, in the meantime female goats were the average age at first sexual maturity in Ancher and Gemechis districts was $7.8 \pm 0.07$ and 7.6 \pm 0.06 months, respectively. The average age at first sexual maturity was significant $(P<0.05)$ difference for both sexes across the two study sites. The variation might be due to breed, availability of forage, environment and presence of breeding male in the flock (for females). This report disagreement with the report of [14] in siti area, were reported that $13.43 \pm 0.45$ and $14.83 \pm 0.45$ months age at first sexual maturity for male and female, respectively.

The age at first kidding for Ancher and Gemechis district goats mean at $12.9 \pm 0.15$ and $12.5 \pm 0.14$ months, respectively, which was significantly association $(P<0.05)$ between districts and age at first kidding. Kidding interval is one of the key mechanism of reproductive performances of a given farm animal production which affects the overall economic go back. There was no significant association between district $(P>0.05)$ and kidding interval. Kidding interval of does in Ancher and Gemechis districts were 8.1 \pm 0.06 and $8.0 \pm 0.07$ months, respectively. The present finding almost similar with the report of (9) in Bati, Borena and Siti areas was reported that $7.95 \pm 0.19,8.42 \pm 0.17$ and $8.81 \pm 0.18$ months, respectively. However, higher when contrasted with report of [14] in Lare and Jikawo districts on Nuer goat, $7.41 \pm 0.68,7.5 \pm 0.62$ and [10] in Gode, Denan and Adadle districts on Shabelle (Somalia) goat, $7.32 \pm 0.13,7.17 \pm 0.07$ and $6.92 \pm 0.08$ months were reported that kidding interval of goat, respectively. There was no significant association between district and number of kid doe in her lifetime. Overall, mean of number of kid doe in her lifetime were 14.2 months. The overall mean number of kid doe in her life time in the study area reported in the present study was close to the reports of [15] and [10] who reported $13.7 \pm 0.23$ and 13.46 \pm 0.20 months for Bale and Somalia (Shabelle) goat, respectively. However, higher when compared with the reports of [12] in Ziquala, Tanqua Abergelle, Lay Armachiho districts and [14] in Bati, Borena, Siti area who reported $8.65 \pm 3.00,8.10 \pm 2.56,7.85 \pm 5.50$ and $11.08 \pm 0.25,9.77 \pm 0.15$, $9.04 \pm 0.16$ were give number of kid doe per her life time, respectively.

There was no significant association between district $(P>0.05)$ and reproductive life span. The overall reproductive life span of female in the study area was $8.7 \pm 0.05$ years. It was higher than the finding of [15] for Bale goats who reported that the reproductive life span of goat was 8.4 years. Also disagreement with the report of [11] for Hararghe Highland goats in East Hararghe zone reported that the reproductive life span was 7.45 years. Average reproductive life time was not recorded for buck due to majority of respondents in the study area was not have knowledge about the end reproductive life time of male goat. In accretion, farmers do not keep buck for more than 18 months (minimum) - 36 months (maximum) due to majority of farmers in both study sites practiced castration (fattening), sale of male at early age for cash income generation.

Table 10. Reproductive performance of goat in the study area.

\begin{tabular}{llll}
\hline & \multicolumn{2}{l}{ Districts } & Overall \\
\cline { 2 - 3 } & Ancher & Gemechis & p-value \\
\cline { 2 - 3 } & Mean \pm SE & Mean \pm SE & \\
\hline Reproductive traits & & & \\
Age at first sexual maturity male (m) & $7.6 \pm 0.07$ & $7.4 \pm 0.06$ & $7.5 \pm 0.05$ \\
Age at first sexual maturity female (m) & $7.8 \pm 0.07$ & $7.6 \pm 0.06$ & $7.7 \pm 0.05$ \\
Age at first kidding (m) & $12.9 \pm 0.15$ & $12.5 \pm 0.14$ & $12.7 \pm 0.11$ \\
Kidding interval (m) & $8.1 \pm 0.06$ & $8.0 \pm 0.07$ & $8.1 \pm 0.04$ \\
Number of Kids doe in her life time & $14.4 \pm 0.17$ & $14.1 \pm 0.23$ & 0.034 \\
Reproductive life time of doe (year) & $8.8 \pm 0.09$ & $8.6 \pm 0.06$ & 0.03 \\
\hline
\end{tabular}

$\mathrm{N}=$ number of respondents $\mathrm{SE}=$ standard Error, $\mathrm{m}=$ month

\section{Conclusion}

This study was conducted, to describe breeding objective, selection criteria and breeding system of indigenous goat type in Ancher and Gemechis districts, Eastern Ethiopia. Majority $(92.5 \%)$ of households in the study area practiced castration while about $7.4 \%$ of household in the study area do not practiced castration. The motivation for the castration of goats across the two surveyed areas was mainly to improve fattening to get better price in local markets. Most (61.4\%) of households in Ancher district reported body confirmation was major selection criteria for male castration followed by age $(29.5 \%)$ and $(8.8 \%)$ color while in Gemechis district
(67.6\%) of household reported body confirmation was selection criteria for castration male goat followed by age $(25.9 \%)$ and color $(6.5 \%)$ respectively. Total of $94.6 \%$ (92.5\% of the household in Ancher and $96.7 \%$ of respondents in Gemechis) were practiced goat fattening. The farmers in Ancher district were rearing their goats primary for cash income followed by meat, manure, milk, saving, skin with an index of $0.37,0.22,0.17,0.15,0.03$ and 0.05 , respectively. Similarly many respondents in Gemechis district were rearing their goats primary for cash income followed by meat, manure, milk, saving, skin with an index of $0.42,0.22$, $0.16,0.11,0.04$ and 0.06 , respectively. Appearance or confirmation of breeding buck was the most important 
selection criteria for Ancher and Gemechis goat owners with an index of 0.38 and 0.31 , respectively. Color and testicular characteristic were ranked second and third with an index of 0.26 and 0.15 in Ancher district. In Gemechis color and horn were ranked second and third important selection criteria with an index of 0.25 and 0.19 , respectively. Among selection criteria considered, appearance, color and better milk yield as first three doe selection criteria in Ancher district with an index $0.33,0.29$ and 0.15 respectively. Similarly, appearance, color ranked first and second in Gemechis district with an index of $0.29,0.23$ respectively, while twinning ranked as third criteria with an index of 0.17 . Type of breeding was generally uncontrolled in both Ancher and Gemechis district with $98.3 \%$ and $100 \%$, respectively. The main reason of uncontrolled mating was lack of awareness about the effect of inbreeding, communal grazing, insufficient number of buck. Small flock size, uncontrolled mating, low level of literacy especially in Ancher, absence of breeding buck in many of the flocks, utilization of breeding buck born within the flock, lack of awareness about inbreeding was the major threats for designing and implementing goat breeding programs. The main use of breeding buck in the study area was for mating purpose $(98 \%)$ followed by social culture $(2 \%)$. Majority $(88.2 \%)$ of the respondents in the study area did not make special management for buck. Household who have no their own buck have used neighbor buck $(68.3 \%)$, communal grazing area $(22.7 \%)$ and unknown $(9 \%)$ to mate their does. Therefore, any breed improvement strategies that are intended to be implemented in the study area and otherwisewhere should consider the traditional breeding practices and breeding objectives of the community.

\section{Recommendations}

Higher level of fattening practices in the area need to scale-up in the surrounding and other areas, in addition to its contribution for the family income, it would also be serve as means of culling unwanted bucks from breeding. Small flock size, use of bucks born in the flock, lack of awareness about inbreeding, and tethering (flock mixing is not common) tends to raise the level of inbreeding. Thus looking for mechanism to encourage buck sharing is and awareness creation would be crucial to decrease the rate of inbreeding by increasing the effective population size.

\section{Acknowledgements}

We would like to express our sincere appreciation to districts Administration office and Livestock Development, all staff members for providing the necessary baseline data for this study. We would like to appreciate and acknowledge the farmers who participated on the interview. We would also like to acknowledge the Development Agents in the study Peasant Associations for their critical support in data collection. We would like to Thank Mizan Tepi University to provide fund for this study.

\section{References}

[1] CSA (Central Statistics Agency). 2017. Agricultural sample survey, 2017 (2009 E.C). Volume II, Report on livestock and livestock characteristics. Statistical bulletin, 570, April 2013, Addis Ababa, Ethiopia.

[2] Gurmessa Umeta, Misgana Duguma, Feyisa Hundesa and Merga Muleta, 2011b. Participatory analysis of problems limiting goat production at selected districts of East Showa zone, Ethiopia. African J. Agril. Res. 6 (26): 5701-5714.

[3] Urgessa Dhaba, Duguma Belay, Demeke Solomon and Tolamariam Taye, 2012. Sheep and Goat Production Systems in Ilu Abba Bora Zone of Oromia Regional State, Ethiopia: Feeding and Management Strategies Global Veterinaria 9 (4): pp 421-429.

[4] Halima Hassen \& Samer Lababidi \& Barbara Rischkowsky \& Michael Baum \& Markos Tibbo, 2012. Molecular characterization of Ethiopian indigenous goat populations. DOI 10.1007/s11250-011-0064-244: pp. 1239-1246.

[5] Mbuku, S. M., Kosgey, I. S. and Kahi, A. K., 2006. Indigenous breeding practices of pastoralist goat keepers in northern Kenya. $8^{\text {th }}$ World Congress on Genetics Applied to Livestock Production, 13-18 August 2006, Belo Horizonte, MG, Brasil.

[6] Kahi, A. K., Rewe, T. O. and Kosgey, I. S. 2005. Sustainable community-based organisations for the genetic improvement of livestock in developing countries. Outlook Agric. 34 (4): 261-270.

[7] Workneh Ayalew and J. Rowlands (eds), 2004. Design, execution and analysis of the livestock breed survey in Oromiya Regional State, Ethiopia. OADB (Oromiya Agricultural Development Bureau), Addis Ababa, Ethiopia, ILRI (International Livestock Research Institute), Nairobi, Kenya.

[8] SPSS Version. 20.0. 2007. Software Package for Social Sciences for Window.

[9] Falconer, D. S. and T. F. C. Mackay, 1996. Introduction to Quantitative Genetics. 4th ed. Harlow, England, Longman. 438 P.

[10] Alefe Takele, 2014. Phenotypic characterization of indigenous goat types and their production system in shabelle zone, south eastern Ethiopia. M.Sc. thesis presented to School of Graduate Study of Haramaya University.

[11] Mahilet Dawit, 2012. Characterization of hararghe highland goat and their production system in eastern hararghe. MSc. Thesis Haramaya University.

[12] Alubel Alemu, 2015. On farm phenotypic characterization and performance evaluation of Abergelle and Central Highland goat breeds as an input for designing community basedbreeding program in Ahmara National Regional State and Tigray National Regional State, Ethiopia. M.Sc. thesis presented to School of Graduate Study of Haramaya University. 128pp.

[13] Tsigabu Gebereselassie Gezahegn, Getahun Asebe Gulich, Kefelegn Kebede and Yosef Mekasha, 2015. Haramaya University, College of Agriculture and Natural Resource, Ethiopia Phenotypic characterization of goat type in Nuer Zone of Gambella People Regional State, South Western Ethiopia ISSN: 2408-5502 Vol. 3 (5), pp. 164-180. 
[14] Hulunim Gebrekiros, 2014. On- Farm Phenotypic Characterization and Performance Evaluation of Bati, Borena and Short Earned Somali Goat Population of Ethiopia. M.Sc. thesis presented to School of Graduate Study of Haramaya University. 141PP.

[15] Belete Assefa, 2013. On farm phenotypic characterization of indigenous goat types and their production system in Bale Zone Of Oromia Region, Ethiopia M.Sc. Thesis. pp. 116.
[16] Armstrong, J. B., 2006. Inbreeding: Why we will not do it? Accessed on September 15, 2008 from http://www.parispoodles.com/Inbreeding.html. 